\title{
Dermatophyte Examination of Skin Scrapings Collected from a Camel: A Case Study
}

\author{
Subha Ganguly ${ }^{1 *}$, Parveez Ahmad Para ${ }^{2}$ and Praveen Kumar Praveen ${ }^{3}$ \\ ${ }^{1}$ Department of Veterinary Microbiology, ${ }^{2}$ Department of Livestock Products Technology, \\ ${ }^{3}$ Department of Veterinary Public health and Epidemiology, Arawali Veterinary College \\ (Affiliated with Rajasthan University of Veterinary and Animal Sciences, Bikaner), N.H. - 52 \\ Jaipur Road, V.P.O. Bajor, Sikar - 332001, Rajasthan, India \\ *Corresponding author
}

\begin{tabular}{|l|l|}
\hline \multicolumn{1}{l}{ A B S T R A C T } \\
\cline { 2 - 2 } \begin{tabular}{l}
\hline Keywords \\
$\begin{array}{l}\text { Superficial } \\
\text { dermatophyte skin } \\
\text { infection, } \\
\text { Skin scraping. }\end{array}$
\end{tabular} & $\begin{array}{l}\text { The present article reports on the laboratory examination of skin scraping sample } \\
\text { collected from a camel clinically infected with dermatophyte infection. The } \\
\text { samples were examined by direct microscopical examination by placing the skin } \\
\text { scrapings and/or hairs in 20\% KOH on a glass slide and gentle heating, without } \\
\text { boiling. The dermatophyte identification was made based on the colony } \\
\text { characteristics and microscopic features of the fungal isolates according to the } \\
\text { methods. The present study revealed the presence of superficial dermatophyte skin } \\
\text { infection in the affected camel. The recommended therapy was suggested to the }\end{array}$ \\
\hline $\begin{array}{l}\text { Accepted: } \\
\text { 24 January 2017 } \\
\text { Available Online: } \\
\text { 10 February 2017 }\end{array}$ & $\begin{array}{l}\text { T.V.C.C. for administration to the camel in divided doses on alternate daily } \\
\text { intervals preferably in mixed preparations. }\end{array}$ \\
\hline
\end{tabular}

\section{Introduction}

Dermatophytosis is a superficial infection of the keratinizd layers of the skin and its appendages (hair, feathers, horns) of farm, domesticated and wild animals and birds. The lesions are frequently ring shaped, hence the disease is called ring worm. Some dermatophytes have great zoonotic importance, where many of them occurring primarily in animals and can be transmitted from infected animals to man (Nakamura et al., 1999). Dermatophytes are filamentous fungi which invade keratinized tissues of humans and animals, causing mild to severe, localized and/or diffuse infections. Zoophilic and Geophilic dermatophytes infect both animals and humans, whereas anthropophilic ones are mainly found on humans (Cafarchia et al., 2013). It is caused by haematogenous group of keratinophylic fungi called the dermatophytes. Dermatophytes are noninvasive cannot survive in living tissues nor in areas of intense inflammation and they have keratolytic activity. Infection is generally restricted to the non-living cornified layers. Dermatophytosis is a clinical entity caused by the members of anamorph genera Microsporum, Trichophyton and Epidermophyton (Weitzman and Summerbell, 1995; Ainswoth, 1973; Balows et al., 1990; Ganguly et al., 2015; Ganguly, 2016). 
In addition to the dermatophytic fungi, other yeasts and molds are sometimes involved in the coetaneous infection (Beneke and Rogers, 1990).

\section{Materials and Methods}

The skin scrapings were collected from the scaly and alopecic lesions on the skin of an affected camel presented for clinical examination at the Teaching Veterinary Clinical Complex (T.V.C.C.) of Arawali Veterinary College, Sikar, during December, 2016. The collected skin scraping samples were then brought to the Department of Veterinary Microbiology for mycological examination and reporting.

The samples were examined by direct microscopical examination by placing the skin scrapings and/or hairs in $20 \% \mathrm{KOH}$ on a glass slide and gentle heating, without boiling. Boiling may cause precipitation and crystal formation that will make examination of specimens difficult (Carter and Cole, 1990). Superchrome blue-black ink or a simple stain mixed 1 part in 9 parts of $\mathrm{KOH}$ was used to examine the fungus elements and spores in scrapings, if any. The cover slip was placed on the preparation and examined under low power magnification.

The sample after incubation in Sabouraud's dextrose broth was then inoculated on Sabouraud's dextrose agar by spread plate method. The acidity of the agar inhibited the growth of most bacteria and encouraged the growth and culture of dermatophytes (Jungerman and Schwartzman, 1972).

The dermatophyte identification was made based on the colony characteristics and microscopic features of the fungal isolates according to the methods described by Rippon (1988) and Larone (1995).

\section{Results and Discussion}

The incubated Sabouraud's dextrose broth sample was subjected to spread plate culture on Sabouraud's dextrose agar (SDA) media with chloramphenicol and cyclohexamide. The media was incubated at $27^{\circ} \mathrm{C}$ for two weeks. Staining with crystal violet dye mixed 1 part in 9 parts of $\mathrm{KOH}$ outlined the fungus elements and spores (arthrospores) microscopically in the scrapings. The fungal colonies were obtained on SDA followed by incubation at $27^{\circ} \mathrm{C}$ for 15 days. It revealed the presence of characteristic colonies spreading in nature with characteristic greyish-white cottony woolly mycelia after incubation. On SDA media, colonies were small, button shaped, white to cream-coloured colonies with a velvety surface, raised centre and flat periphery.

Trichophyton verrucosum is the most common dermatophyte that affects camels (Abdalla and Salim, 2010; Fadlelmula et al., 1994; Wisal et al., 2010)

The results obtained in the present study were in concurrence to the findings of Moore and Jaciow (1979), Monga and Mohapatra (1980), Mukherji et al., (1992), Kuttin et al., (1986) and Almuzaini et al., (2016). Almuzaini et al., (2016) had concluded that ringworm is a common disease affecting young dromedary camels below three years of age and $T$. verrucosum is a common cause.

\section{Recommended Therapy}

a) Topical application of imidazole derivatives (cotrimazole, econazole, miconazole, bifonazole, triconazole).

b) Griseofulvins (10 mg/kg b.wt. per day) and Ketoconazole (Nizoral) to be administered orally.

c) Systemic preparations of thiabendazole. 
d) Vit. A and mineral supplementation besides topical application with iodine ointment enhance the recovery rate (Abdalla and Salim, 2010).

In conclusion, the present study revealed the presence of superficial dermatophyte skin infection in the affected camel. The recommended therapy was suggested to the T.V.C.C. for administration to the camel in divided doses on alternate daily intervals preferably in mixed preparations.

\section{Acknowledgements}

The authors are thankful to Hon'ble Dean and Management (Hon) Chairman and Secretary, Aastha Society, Sikar) of Arawali Veterinary College for providing the necessary facilities to carry out the lab diagnostic work.

\section{References}

Abdalla, W.G. and Salim, M.O. 2010. Isolation and identification of dermatophytes from infected Camels. Sudan J. Vet. Res., 25:94-53.

Abdulaziz, M., Almuzaini, Salama, A., Osman, Elhassan, M.A. Saeed. 2016. An outbreak of dermatophytosis in camels (Camelus dromedaríus) at Qassim Region, Central of Saudi Arabia. J. Applied Animal Res., 44: 1, 126-129.

DOI: 10.1080/09712119.2015.1021806

Ainswoth, G.C. and Austwick, P.K.C. 1973. Fungal diseases of animals. $2^{\text {nd }}$ ed. Commonwealth Agricultural Bureaux, Farnham, England.

Balows, A., Hansler, W.J., Ohashi, M. and Turano, A. 1990. Laboratory diagnosis of infectious diseases, Principles and Practice. Vol. 1. Bacterial, Mycotic and Parasitic Diseases. Springer-Verlag NY, London, Paris, Tokyo.

Beneke, E.S. and Rogers, A.L. 1980. Medical
Mycol. Manual, $4^{\text {th }}$ ed. Minneapolis, Burgess.

Cafarchia, C., Iatta, R., Latrofa, M.S., Graser, Y. and Otranto, D. 2013. Molecular epidemiology, phylogeny and evolution of dermatophytes. Inf. Genet. Evol., 20: 336-351.

Carter, G.R. and Cole, J.R. 1990. Diagnostic procedures in veterinary bacteriology and mycology. Academic press, Inc. NY, Boston, London, Sydney, Tokyo, 1990.

Jungerman, P.F. and Schwartzman, R.M. 1972. Vet. Mycol., Philadephia, Lea and Febiger.

Larone, D.H. 1995. Medically important fungi: a guide to identification. 3rd ed. Washington (DC): ASM Press, 1995.

Fadlelmula, A., Agab, H., Le Horgne, J.M., Abbas, B. and Abdalla, A.E. 1994. First isolation of Trichophyton verrucosum as the aetiology of ringworm in the Sudanese camels (Camelus dromedarius). Revue d,Elevage Et De Medicine Veterinaire Des Pays Tropicaux, 47:184-187.

Ganguly, S. 2017. Mycological examination of camel skin scrapings. In: Proceedings of the One day State level Seminar on "Recent Trends in Zoology" (January 20, 2017) at Mula Education Society's Shri Dnyaneshwar Mahavidyalaya, Tal. Newasa, Dist. Ahmednagar sponsored by B.C.U.D. Savitribhai Phule Pune University, Pune, pp. xx-xx [ISBN: $\mathrm{xxxx}-\mathrm{XxX}-\mathrm{Xxx}-\mathrm{x}]$. In process.

Ganguly, S., Padhy, A., Para, P.A., Sahoo, A., Sharma, S., Pandey, A.K., Praveen, P.K. and Saroj. 2015. Basic guidelines and procedures for the clinical and laboratory diagnosis of Mycotic infections in animals: A general overview of veterinary importance. $J$. Lab. Life Sci., 1(1): 1-10.

Kuttin, E.S., Alhanaty, E., Feldman, M., Chaimovits, M. and Müller, J. 1986. 
Dermatophytosis of camels. J. Med. Vet. Mycol., 24(4): 341-44.

Monga, D.P. and Mohapatra, L.N. 1980. A compilation of published reports of mycoses in animals in India. Mycopathologia, 72: 3-11.

Moore, G.S. and Jaciow, D.M. 1979. Mycology for the clinical laboratory. Reston Publishing Co., Inc, Reston, Virginia.

Mukherji, K.G., Srivastava, K., Singh, K.P. and Garg, K.L. 1992. Advances in medical mycology. Aditya Books Pvt. Ltd., New Delhi.
Nakamura, Y., Watanabe, S. and Hasegawa, A. 1999. Dermatomycosis in human and animals. Nippon Ishinkin Gakkai Zasshi, 40:9-14.

Rippon, J.W. 1988. Medical Mycology. $3^{\text {rd }}$ ed. Philadelphia, Saunders, 1988.

Wisal, G. Abdalla and Salim, M.O. 2010. Isolation and identification of dermatophytes from infected Camels. Sudan J. Vet Res., 25: 94-53.

Weitzman, I. and Summerbell, R.C. 1995. The dermatophytes. Clin. Microbiol. Review, 8:240-259.

\section{How to cite this article:}

Subha Ganguly, Parveez Ahmad Para and Praveen Kumar Praveen. 2017. Dermatophyte Examination of Skin Scrapings Collected from a Camel: A Case Study. Int.J.Curr.Microbiol.App.Sci. 6(2): 1731-1734. doi: http://dx.doi.org/10.20546/ijcmas.2017.602.193 